\title{
Primary sclerosing cholangitis
}

\author{
Marina G Silveira MD, Keith D Lindor MD
}

\section{MG Silveira, KD Lindor. Primary sclerosing cholangitis. Can J Gastroenterol 2008;22(8):689-698.}

Primary sclerosing cholangitis (PSC) is a chronic cholestatic liver disease characterized by inflammation and fibrosis of the bile ducts, resulting in end-stage liver disease and reduced life expectancy. PSC primarily affects young and middle-aged men, often in association with underlying inflammatory bowel disease. The etiology of PSC includes immune-mediated components and elements of undefined nature. A cholestatic picture of liver biochemistries with elevations in serum alkaline phosphatase, nonspecific autoantibodies such as perinuclear antineutrophilic antibody, antinuclear antibodies and smooth muscle antibodies, and diffuse multifocal biliary strictures, resulting in a 'beaded' appearance on radiographic studies, are the hallmarks of the disease. No effective medical therapy is currently available, although clinical studies are in progress. Ursodeoxycholic acid at high doses ( $28 \mathrm{mg} / \mathrm{kg} /$ day to $30 \mathrm{mg} / \mathrm{kg} /$ day $)$ is the most promising agent but is unproven so far. Liver transplantation is currently the only life-extending therapy for patients with end-stage disease, although recurrent disease can be observed in the transplanted liver. The multiple complications of PSC include pruritus, fatigue, vitamin deficiencies, metabolic bone disease, peristomal varices, bacterial cholangitis, dominant biliary strictures, gallbladder stones and polyps, and malignancy, particularly cholangiocarcinoma, which is the most lethal complication of PSC.

Key Words: Cholangiocarcinoma; Cholestasis; Diagnosis; Liver transplantation; Sclerosing cholangitis; Therapy

\section{Cholangite sclérosante primaire}

La cholangite sclérosante primaire (CSP) est une maladie hépatique cholestatique chronique caractérisée par une inflammation et une fibrose des canaux biliaires; elle provoque une maladie du foie terminale et abrège l'espérance de vie des patients. La CSP affecte principalement les hommes jeunes et d'âge moyen, souvent en lien avec une maladie inflammatoire de l'intestin sous-jacente. L'étiologie de la CSP inclut des composantes immunitaires et des éléments de nature indéterminée. Le tableau cholestatique des analyses biochimiques hépatiques avec élévation de la phosphatase alcaline sérique, la présence d'auto-anticorps non spécifiques tels qu'anticorps antineutrophiles périnucléaires, anticorps antinucléaires et anticorps anti-muscles lisses, en plus de strictures biliaires multifocales diffuses apparaissant en « collier de perles » à la radiographie, sont caractéristiques de la maladie. On ne dispose, pour l'instant, d'aucun traitement médicamenteux efficace, bien que certaines études cliniques soient en cours. L'acide ursodésoxycholique à forte dose (de $28 \mathrm{mg} / \mathrm{kg} / \mathrm{jour}$ à $30 \mathrm{mg} / \mathrm{kg} /$ jour) est l'agent le plus prometteur, mais son effet n'est pas encore éprouvé. La transplantation hépatique est actuellement le seul traitement qui puisse prolonger la vie des patients atteints de la maladie à un stade terminal, mais une récurrence de la maladie s'observe dans les foies transplantés. Parmi les multiples complications de la CSP, mentionnons le prurit, la fatigue, les carences vitaminiques, la maladie osseuse métabolique, les varices péristomiales, la cholangite bactérienne, les strictures biliaires dominantes, les calculs biliaires et les polypes et la néoplasie, particulièrement le cholangiocarcinome, qui est la complication la plus mortelle de la CSP.
Drimary sclerosing cholangitis (PSC) is a chronic cholestatic liver disease that primarily affects young and middleaged men, especially patients with underlying inflammatory bowel disease (IBD) $(1,2)$. The etiology of PSC is undefined, apart from an increasing body of evidence that points to an autoimmune process as a component of the disease. A variety of therapeutic agents with different mechanisms of action have been evaluated in the treatment of this disease, none of which have shown convincing benefit. Among eligible patients, liver transplantation is currently the only lifeextending therapy for patients with end-stage PSC. Although PSC is an uncommon disease, it is among the most common indications for liver transplantation in Europe and the
United States $(3,4)$. The increased risk for cholangiocarcinoma (CCA) in patients with PSC contributes to the high morbidity and mortality of this disease (3).

\section{EPIDEMIOLOGY}

Approximately two of three PSC patients are male, and affected individuals are young (mean age at diagnosis is approximately 40 years). A large proportion of patients with PSC have associated IBD $(1,5)$; the association is higher in patients of Northern European descent (6). The only population-based estimates of incidence and prevalence of PSC conducted in the United States revealed rates of 0.90 per 100,000 person-years and 13.6 per 100,000 persons,

Division of Gastroenterology and Hepatology, Miles and Shirley Fiterman Center for Digestive Diseases, Mayo Clinic and Foundation for Medical Education and Research, Rochester, Minnesota, USA

Correspondence: Dr Keith D Lindor, 200 First Street Southwest, Rochester, Minnesota 55905, USA. Telephone 507-284-2969, fax 507-266-4531, e-mail lindor.keith@mayo.edu

Received and accepted for publication April 29, 2008 


\section{TABLE 1}

Prevalence of primary sclerosing cholangitis symptoms

\begin{tabular}{lc}
\hline Symptom & Frequency, \% \\
\hline None & $15-55$ \\
Fatigue & $50-75$ \\
Pruritus & $40-70$ \\
Jaundice & $9-69$ \\
Abdominal pain & $16-60$ \\
Weight loss & $10-34$ \\
Fevers and chills & $5-28$ \\
Hyperpigmentation & 25
\end{tabular}

Data from references 2,10-14,98,106,145

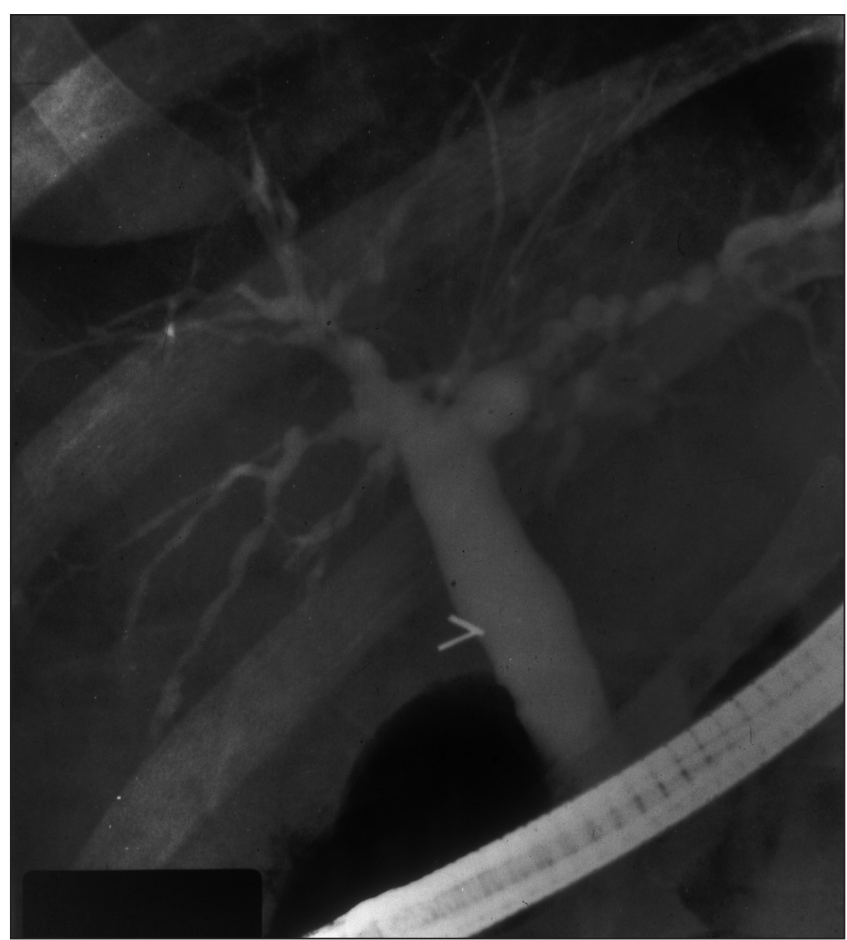

Figure 1) Cholangiographic findings. Endoscopic retrograde cholangiogram demonstrating multifocal strictures with intervening saccular dilation of both intrahepatic and extrahepatic bile ducts, which is characteristic of primary sclerosing cholangitis

respectively (7). Population-based studies of disease frequency are also available from Sweden (8), Norway (9), Great Britain (10) and Canada (11), and indicate comparable incidence and prevalence.

\section{Clinical features}

\section{DIAGNOSIS}

At presentation, approximately $15 \%$ to $55 \%$ of PSC patients are asymptomatic (11-14). Patients are at increased risk for developing symptoms over time (2). Table 1 illustrates the described prevalence of symptoms in several PSC studies. Fatigue, pruritus, jaundice or abdominal discomfort develops in $60 \%$ of cases. Symptoms such as pruritus and right upper abdominal pain are the most common intermittent symptoms, occurring with considerable individual variation and resolving spontaneously, in most cases (15).

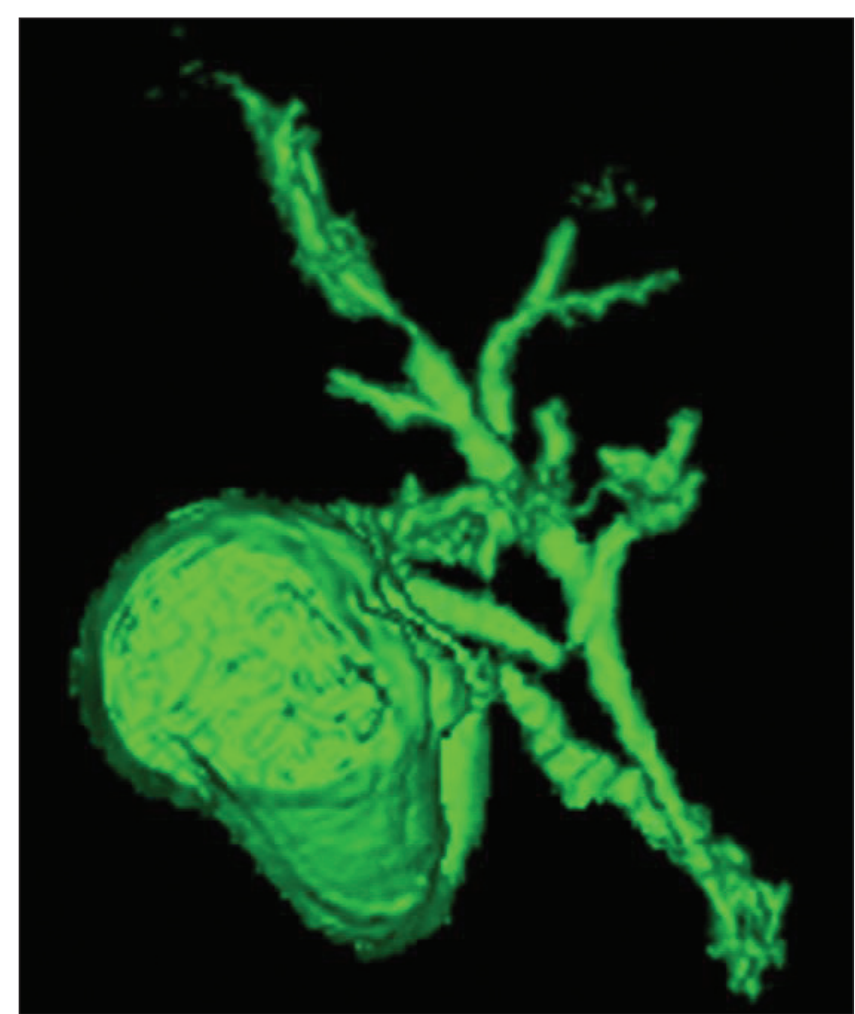

Figure 2) Cholangiographic findings. Magnetic resonance cholangiogram with three-dimensional reprocessing demonstrating characteristic findings of primary sclerosing cholangitis

\section{Biochemical features}

A cholestatic picture of liver function with an elevation in serum alkaline phosphatase level is the biochemical hallmark of PSC (1), although some patients may have normal alkaline phosphatase levels (16). Increases in serum aspartate and alanine aminotransferase levels are usually only mild to moderate. Patients with PSC often have fluctuations in bilirubin and alkaline phosphatase levels during the course of the disease. Periods of clinical and cholestatic relapses follow periods of clinical remission with less cholestasis (17).

\section{Serological features}

Currently, testing for specific autoimmune antibodies does not contribute to the diagnosis of PSC. Multiple autoantibodies can be detected in PSC. Antinuclear antibodies and smooth muscle antibodies can be found in $20 \%$ to $60 \%$ of patients, usually in lower titres than those observed in autoimmune hepatitis (18). In contrast, antimitochondrial antibodies are seldom seen in patients with PSC (1). The prevalent autoantibody reactivity is a perinuclear antineutrophilic autoantibody (perinuclear antineutrophil cytoplasmic antibody), present in approximately $80 \%$ of patients, but lacking in diagnostic specificity (19-22).

\section{Radiographic features}

Diagnostic features include diffuse multifocal strictures, usually involving both the intrahepatic and extrahepatic ducts (Figures 1 and 2). Strictures are typically short and annular, alternating with normal or minimally dilated segments to produce a characteristic 'beaded' appearance (23). 


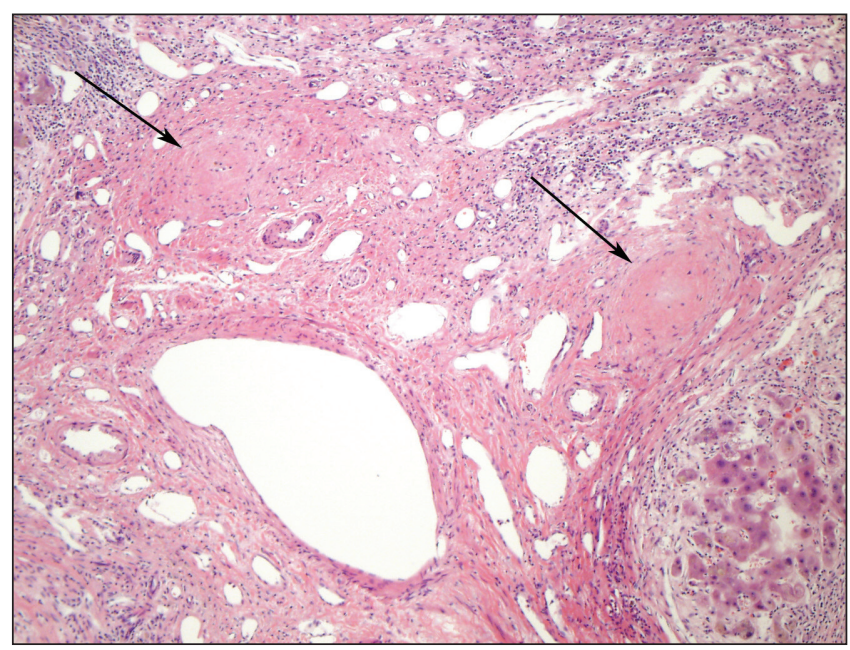

Figure 3) Histological findings. Expanded portal area with two distinct fibro-obliterative lesions (arrows) in end-stage primary sclerosing cholangitis. There is no intact bile duct present in this portal area; only cross-sections of portal vein and hepatic artery branches (hematoxylin and eosin stain; original magnification, $\times 100$ ). Photograph courtesy of Dr Schuyler Sanderson

Cholangiography is considered to be the gold standard for the diagnosis of PSC (5) and is still commonly used, not only for diagnosis, but also therapeutically to dilate or stent the dominant stricture and screen for CCA by way of brush cytology and biopsy. Endoscopic retrograde cholangiography (ERC) in patients with PSC is associated with a risk for complications such as cholangitis, pancreatitis, bile duct perforation and stent migration. Repeated ERC in patients with PSC may increase the likelihood of seeding the biliary system with bacteria, possibly causing disease progression. Multiple studies (24-26) have described highly variable rates of endoscopyrelated complications in PSC patients, ranging from $3 \%$ to $18 \%$. A recent study (27) comparing therapeutic ERC in patients with PSC and those with other biliary strictures, showed that the complication rates were similar, but PSC patients with acute symptoms had a higher rate of complications than those whose procedures were performed electively.

Magnetic resonance cholangiography (MRC) for detecting PSC has emerged as an accurate, rapid, noninvasive alternative examination of the biliary tract, and is commonly used in multiple centres. Other advantages of MRC over ERC include cost savings (26) and the lack of radiation exposure (28). The major disadvantage of MRC is that it is a purely diagnostic examination, although it can be used to identify patients who would benefit from subsequent therapeutic ERC (29).

\section{Histological features}

PSC is histologically characterized by damage, atrophy and, ultimately, loss of medium- and large-sized bile ducts, within or outside the liver $(30,31)$. These are not typically captured in a percutaneous liver biopsy. The smaller ducts are affected by the resultant obstruction and gradually disappear (ductopenia). The characteristic pathological feature of PSC is concentric periductal fibrosis ('onion-skinning'), which progresses to a narrowing and then obliteration of the small bile ducts, leaving a bile duct scar (Figure 3). However, this is found in less
TABLE 2

Differential diagnoses and variant syndromes of primary sclerosing cholangitis

Secondary sclerosing cholangitis

Portal hypertensive biliopathy

Ischemic-like cholangiopathy in critically ill patients

Overlap syndrome of primary sclerosing cholangitis and autoimmune

hepatitis

Immunoglobulin G subclass 4-associated cholangitis

Data from references $146-150$

than $15 \%$ of patients with PSC (32). Frequently, findings are nonspecific and must be interpreted along with clinical and radiological information.

One main staging system for PSC has been devised. Ludwig et al (33) described four stages of PSC: cholangitis or portal hepatitis (stage 1); periportal fibrosis or periportal hepatitis (stage 2); septal fibrosis, bridging necrosis or both (stage 3); and biliary cirrhosis (stage 4).

The role of liver biopsy in the evaluation of PSC appears to be of limited value (32). Despite its potential usefulness for disease diagnosis, exclusion of alternative diagnoses and estimation of prognosis in PSC, caution must be exercised because the histological lesions may be spotty and findings that are consistent with different stages may be present in a single liver simultaneously (34). Diagnosis is usually established by cholangiography and cholestatic liver profile, and in the vast majority of cases, liver biopsy does not reveal atypical findings and does not have any impact on the management of the patient (32). A validated mathematical model for predicting survival in patients with PSC independent of histological findings is available (34). Liver biopsy can be helpful in selected cases, such as in patients with cholestasis and IBD with normal cholangiogram findings, and when small-duct PSC may be diagnosed. It can also be helpful in patients with chronic cholestatic diseases who present with unusually high transaminase levels and hypergammaglobulinemia, when an overlap syndrome of autoimmune hepatitis might be diagnosed and the patients are treated with corticosteroids and immunomodulators.

\section{Differential diagnosis and variant syndromes}

Table 2 highlights differential diagnoses and variant syndromes of PSC.

\section{MANAGEMENT}

\section{Medical treatment}

Different forms of medical treatment have been tried, but no treatment for PSC has been proven to be effective in randomized, controlled studies. Drugs evaluated to date have included budesonide (35), colchicine (36), cladribine (37), cyclosporine (38), etanercept (39), infliximab (40), methotrexate (41), mycophenolate mofetil $(42,43)$, oral and transdermal nicotine $(44,45)$, penicillamine (46), pentoxifylline (47), pirfenidone (48), silymarin (49) and tacrolimus $(50,51)$. Table 3 summarizes the current status of many clinical studies. Despite encouraging results from a few studies, none have demonstrated convincing evidence of benefit and some are associated with significant side effects 
TABLE 3

Medications evaluated in the treatment of primary sclerosing cholangitis

\begin{tabular}{|c|c|c|}
\hline No benefit & Possible benefit & Under consideration \\
\hline Azathioprine & Metronidazole & $\begin{array}{l}\text { UDCA }(28 \mathrm{mg} / \mathrm{kg} / \text { day } \\
\text { to } 30 \mathrm{mg} / \mathrm{kg} / \mathrm{day})^{*}\end{array}$ \\
\hline Budesonide & Minocycline* & $\mathrm{DHA}^{*}$ \\
\hline Cladribine & Silymarin & Thalidomide* \\
\hline Colchicine & Tacrolimus & Nor-UDCA* \\
\hline Cyclosporine & & $6-\mathrm{EDCA}^{*}$ \\
\hline Etanercept & & Losartan* \\
\hline \multicolumn{3}{|l|}{ Infliximab } \\
\hline \multicolumn{3}{|l|}{ Methotrexate } \\
\hline \multicolumn{3}{|c|}{ Mycophenolate mofetil } \\
\hline \multicolumn{3}{|l|}{ Nicotine } \\
\hline \multicolumn{3}{|l|}{ Penicillamine } \\
\hline \multicolumn{3}{|l|}{ Pentoxifylline } \\
\hline Pirfenidone & & \\
\hline
\end{tabular}

Please refer to text for references. *Unpublished or ongoing studies. 6-EDCA 6-alpha-ethyl-chenodeoxycholic acid; DHA Docosahexaenoic acid; UDCA Ursodeoxycholic acid

$(35,42,51)$. Similarly, studies evaluating the combination of low-dose prednisolone and colchicine (52); ursodeoxycholic acid (UDCA) and methotrexate (53); prednisone or budesonide combined with UDCA (54); UDCA, prednisolone and azathioprine (55); and metronidazole and UDCA (56) have not yet shown evidence supporting the long-term use of any particular drug combination. Most of these drugs were evaluated in pilot studies, including a small number of patients treated for a short period of time. The end points used in these studies have been primarily changes in biochemical measurements and Mayo risk score, and little is known about the effects of those drugs on survival free of liver transplantation and overall survival.

UDCA has been the drug most widely evaluated in the treatment of PSC and is the most promising one to date. Several controlled and uncontrolled studies (38-46) have consistently demonstrated that UDCA, in a wide dose range from $10 \mathrm{mg} / \mathrm{kg} /$ day to $30 \mathrm{mg} / \mathrm{kg} /$ day, has beneficial effects on liver biochemistries. To date, the relationship among improvement in liver biochemistries and clinically relevant findings such as the development of cirrhosis and its complications, the need for liver transplantation and survival is unknown (57).

Studies evaluating lower doses of UDCA ( $13 \mathrm{mg} / \mathrm{kg} /$ day to $20 \mathrm{mg} / \mathrm{kg} /$ day) have demonstrated beneficial effects on serum hepatic biochemistries (58), cholangiographic appearance and liver histology after two years of therapy (59), but no difference in predicted survival. Similarly, one study $(60)$ evaluated intermediate doses of UDCA (17 mg/kg/day to $23 \mathrm{mg} / \mathrm{kg} /$ day $)$ and did not observe any significant decrease in serum alkaline phosphatase level in UDCA-treated patients, significant benefit from UDCA on survival without liver transplantation or prevention of CCA. However, the study was too small to exclude a significant beneficial effect on survival. In contrast, higher doses of UDCA ( $25 \mathrm{mg} / \mathrm{kg} /$ day to $30 \mathrm{mg} / \mathrm{kg} /$ day $)$ were associated with substantial reductions, not only in serum hepatic biochemistries but also in Mayo risk score after therapy $(61,62)$. Most of the trials performed to date have been limited by a small number of patients and relatively short follow-up periods, and have not allowed conclusions with regard to effects on survival free of liver transplantation and overall survival. UDCA has not yet been proven to prolong survival or improve the outcome of PSC. A large multicentre, randomized trial sponsored by the National Institutes of Health (63) to evaluate the use of high-dose UDCA ( $28 \mathrm{mg} / \mathrm{kg} /$ day to $30 \mathrm{mg} / \mathrm{kg} /$ day) is currently underway, but results will not be available for at least three years.

\section{Innovative approaches to therapy}

Trials evaluating antibiotics such as metronidazole and minocycline have been promising but inconclusive. A small study (64) of docosahexaenoic acid, which improves cystic fibrosis transmembrane conductance regulator gene function, is currently underway. Most promising for the near future are antifibrotic agents (such as angiotensin-converting enzyme inhibitors, angiotensin receptor blockers and sirolimus/rapamycin), inhibitors of formation of toxic bile (such as 24-norursodeoxycholic acid) (65) and bile acid derivatives (such as 6-alpha-ethyl-chenodeoxycholic acid) (66-69).

\section{Disease-associated complications}

Disease-associated complications of PSC include pruritus, fatigue, steatorrhea and vitamin deficiencies, metabolic bone disease, bleeding peristomal varices, bacterial cholangitis, dominant biliary strictures, gallbladder stones and polyps, and CCA. Table 4 summarizes the proposed treatments for these conditions.

\section{Endoscopic treatment}

Some patients present with clinical and biochemical deterioration, and exhibit a dominant stricture that involves the larger extrahepatic biliary ducts (Figure 4). The incidence of dominant strictures in patients with PSC has been estimated to be as high as $45 \%$ to $58 \%$ (17), whereas others have found a much lower frequency (70). Such lesions may be amenable to endoscopic or radiological dilation with or without a biliary drainage procedure, such as sphincterotomy and stenting (71). This leads to symptomatic, biochemical and radiographic improvement. The use of endobiliary stents in PSC has been associated with greater frequency of intervention-related complications including acute cholangitis; balloon dilation alone is preferred in this population $(70,72)$. Repeated balloon dilations of dominant biliary strictures resulted in improved actual survival rates compared with survival rates predicted by Mayo risk score in two studies $(73,74)$, although the clinical relevance of these results is controversial. No randomized studies have been published demonstrating the benefits of endoscopic treatment in PSC.

\section{Surgical treatment}

Before the widespread use of liver transplantation and endoscopic balloon dilation to manage PSC, surgical resection was used as the predominant method of treatment. Operative management of PSC entails resection of the extrahepatic biliary tree including hepatic duct bifurcation and postoperative transhepatic stenting (75). In carefully selected patients without cirrhosis and with predominantly extrahepatic biliary strictures, resection of the extrahepatic biliary tree may prolong the interval to liver transplantation and provide relief of jaundice (75). Presently, biliary surgery in patients with PSC, other than simple cholecystectomy, should be minimized and 
TABLE 4

Disease-associated complications of primary sclerosing cholangitis and their treatments

\begin{tabular}{|c|c|}
\hline Complication & Treatment \\
\hline \multirow[t]{4}{*}{ Pruritus } & Cholestyramine \\
\hline & Rifampin \\
\hline & $\begin{array}{l}\text { Other agents: opioid antagonists, sertraline, } \\
\text { ondansetron }\end{array}$ \\
\hline & Refractory pruritus: liver transplantation \\
\hline Fatigue & No specific treatment available \\
\hline Vitamin deficiencies & Vitamin supplementation \\
\hline \multirow[t]{2}{*}{ Metabolic bone disease } & Calcium and vitamin D supplementation \\
\hline & Bisphosphonates? \\
\hline \multirow[t]{3}{*}{ Bleeding peristomal varices } & $\begin{array}{l}\text { Local control (usually ineffective over the } \\
\text { long term) }\end{array}$ \\
\hline & Liver transplantation \\
\hline & TIPS \\
\hline \multirow[t]{2}{*}{ Bacterial cholangitis } & Antibiotic therapy \\
\hline & Prophylactic antibiotics before ERCP \\
\hline \multirow[t]{2}{*}{ Dominant biliary strictures } & Endoscopic treatment \\
\hline & Surgical treatment \\
\hline Gallbladder stones & Cholecystectomy for symptomatic stones \\
\hline Gallbladder polyps & $\begin{array}{l}\text { Consideration for cholecystectomy due to } \\
\text { malignant potential }\end{array}$ \\
\hline \multirow[t]{3}{*}{ Cholangiocarcinoma } & Surgical resection \\
\hline & $\begin{array}{l}\text { Liver transplantation protocols with } \\
\text { neoadjuvant chemoradiation }\end{array}$ \\
\hline & $\begin{array}{l}\text { Palliation with endoscopy and } \\
\text { photodynamic therapy }\end{array}$ \\
\hline
\end{tabular}

ERCP Endoscopic retrograde cholangiopancreatography; TIPS Transjugular intrahepatic portosystemic shunt. Data from references 2,29,41,73-75,135, $137,151-158$

reserved for selected rare noncirrhotic patients who have marked cholestasis or recurrent cholangitis caused by a dominant extrahepatic or hilar stricture not amenable to endoscopic or percutaneous dilation (71). In patients who may undergo liver transplantation, previous biliary surgery has been associated with a significantly longer operation time, greater intraoperative blood loss and a higher incidence of biliary complications following liver transplantation compared with those patients with no history of biliary surgery (76-80).

\section{Liver transplantation}

Liver transplantation is the treatment of choice for patients with end-stage disease due to PSC. Liver transplantation should be considered before the disease becomes too advanced, to enhance the long-term survival rates after liver transplantation (81). Prognostic models can aid in the timing of liver transplantation. Unique circumstances that require evaluation for possible liver transplantation include recurrent bacterial cholangitis despite intensive medical and endoscopic therapy, severe extrahepatic biliary obstruction that precludes operative repair and uncontrolled peristomal variceal bleeding. Intractable pruritus may also be an indication for liver transplantation. Over a 12-year period, among patients with PSC, no statistically significant change in the number of patients receiving or listed for transplantation occurred in the United States (82). PSC is among the indications for liver

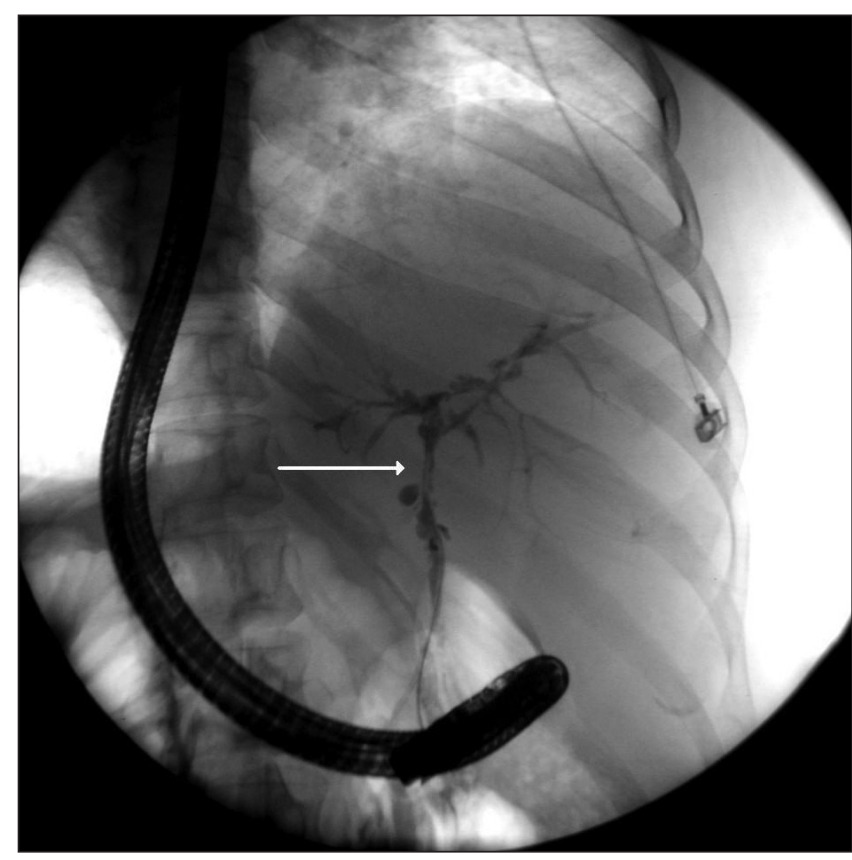

Figure 4) Dominant stricture. Endoscopic retrograde cholangiogram demonstrating characteristic findings of primary sclerosing cholangitis and dominant common hepatic bile duct stricture (arrow)

transplantation with the best patient survival (83). Reports from single centres performing liver transplantation in PSC patients have demonstrated excellent survival rates of $90 \%$ to $97 \%$ at one year, and $83 \%$ to $88 \%$ at five years $(83,84)$. However, retransplantation rates seem to be higher for patients with PSC than for those with other diagnoses (85).

Recurrence of PSC in the liver graft occurs in 2\% to $40 \%$ of the transplanted grafts (86). The different diagnostic criteria used for recurrent PSC and variable length of follow-up account for part of the variation observed. Diagnosis of recurrent PSC can be challenging, because nonspecific bile duct injuries and strictures caused by allograft reperfusion injury, ischemia, rejection and recurrent biliary sepsis can mimic the findings of PSC following transplantation, and need to be carefully excluded before the diagnosis of recurrence can be established $(87,88)$. A set of criteria has been proposed by a group of investigators at the Mayo Clinic (89). These criteria have been increasingly used as the standard tool for diagnosis of recurrent PSC (90). The diagnostic criteria consist of a confirmed diagnosis of PSC before transplantation, cholangiogram showing nonanastomotic biliary strictures occurring more than three months after liver transplantation, exclusion of other conditions associated with biliary strictures, and/or liver biopsy showing fibrous cholangitis and/or fibro-obliterative lesions (89).

Proposed risk factors for recurrent PSC include recipient age (91), male sex (92), sex mismatch (87), coexistent IBD, presence of intact colon after liver transplantation (92), cytomegalovirus infections (91), biologically related living donor liver transplantation (93), recurrent and steroid-resistant acute cellular rejection $(91,94,95)$, muromonab-CD3 for acute cellular rejection $(91,96)$ and maintenance corticosteroids after liver transplantation $(96,97)$. As more liver transplant recipients survive longer, the recurrence of disease may become the primary cause of morbidity and mortality in PSC (86). 


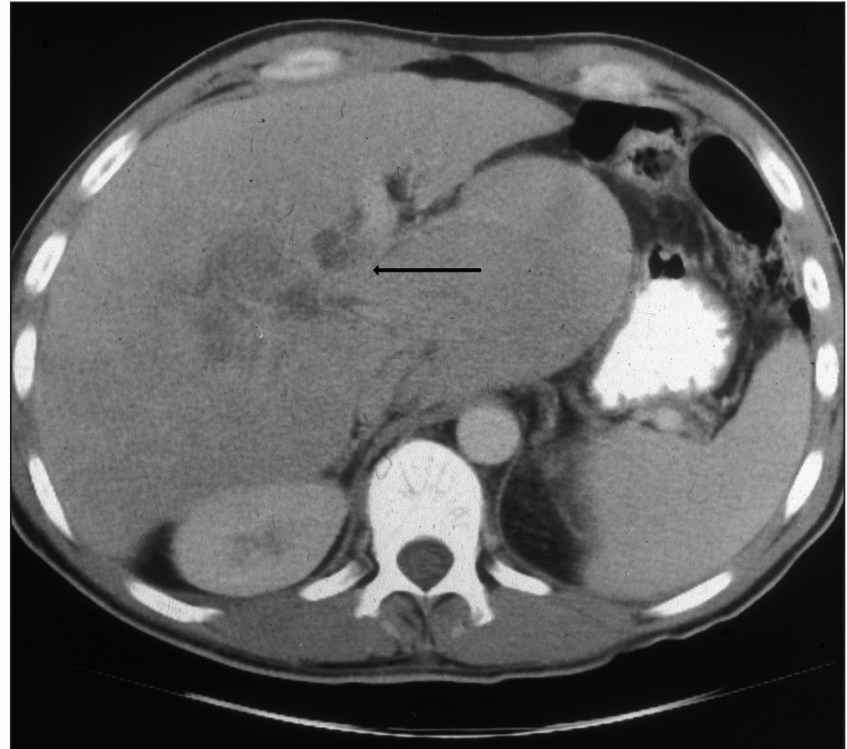

Figure 5) Computed tomography demonstrating cholangiocarcinoma (arrow)

\section{PROGNOSIS}

Although its course is variable from one patient to another, PSC is generally progressive, and usually leads to the development of primary biliary cirrhosis along with its complications. In early cohorts, a median transplantation-free survival of approximately 12 years was observed $(12,13,98)$. More recent reports suggest a median transplantation-free survival of 18 years (99). CCA and liver failure are the two major complications that affect survival in patients with PSC. Over the past 25 years, mortality from PSC in the United States has remained largely unchanged, highlighting the need for effective therapeutic strategies (100).

In PSC, disease progression and prognosis can be established over time by tracking serum bilirubin, alkaline phosphatase and/or the composite Mayo risk score, which is calculated based on measurements of serum bilirubin, aspartate aminotransferase and albumin levels, patient age and the presence of variceal bleeding (34). The use of surrogate end points of disease progression and survival in PSC has been well described (34,101-105). Less is known about the reliability of these biochemical parameters and PSC-Mayo risk score in predicting response to therapy in PSC (57). Other mathematical models have been developed to predict the natural history of the disease in an individual patient in the absence of effective therapy $(12,13,98,99,101,106)$.

\section{Strictures}

A dominant stricture is a frequent finding and occurs in up to $45 \%$ of patients during follow-up $(17,107)$. Stenotic lesions in PSC are thus more often benign than malignant in nature. High-grade intrahepatic but not extrahepatic strictures have been shown to predict poor prognosis in two independent studies $(108,109)$. Recently, however, a combination of intrahepatic and extrahepatic scoring proved to be predictive of survival (99). Further studies are needed to confirm these findings.

\section{CCA}

Patients with PSC are at high risk for developing CCA (Figure 5). CCA is the most feared complication of PSC and occurs in $7 \%$ to $15 \%$ of patients $(13,110-112)$, with an annual incidence of $0.5 \%$ to $1.5 \%(110,112)$. The survival of patients with PSC and CCA is greatly diminished (112). Most cases (37\% to $50 \%$ ) are diagnosed within one year of diagnosis of PSC (111,112). However, CCA can also be a later complication of PSC (106). Although there is no clear association between the duration of PSC and the development of CCA, the presence of cirrhosis may be associated with an increased risk for CCA $(98,106,110)$. Long-term UDCA therapy may reduce the risk of CCA in PSC $(113,114)$.

The diagnosis of CCA can be challenging because its cholangiographic characteristics can imitate the stricturing lesions of PSC (115). The development of CCA is not reliably heralded by symptomatic or biochemical changes. Sudden progressive jaundice, weight loss and abdominal pain are frequently associated with the development of CCA in patients with PSC, but the majority of patients with these symptoms have extrahepatic metastases at the initial diagnosis of CCA (116). Anatomic location of the tumour influences the ease of diagnosis. Hilar tumours are easier to diagnose, with earlier onset of signs and symptoms of biliary obstruction, whereas small or peripheral intrahepatic lesions can be quite challenging, because obstructive symptoms may only be a late finding (117). Elevated alkaline phosphatase and bilirubin levels are not specific for CCA, and may simply be a reflection of progression of the patient's underlying liver disease. A new dominant stricture in patients with PSC merits both immediate investigation and close surveillance, especially in patients manifesting progression or deterioration of their clinical condition.

There are no specific tumour markers for the diagnosis of CCA in patients with PSC. In patients with PSC, ultrasonography and computed tomography seldom identify CCA (118), but can detect duct dilation as a sign of a tumour. Magnetic resonance imaging studies are considered by some to be the optimal noninvasive investigation for suspected CCA (119), particularly with the administration of ferumoxides (Feridex; AMAG Pharmaceuticals Inc, USA) (120). Positron emission tomography using F-fluoro-2-deoxy-D-glucose to assess human tissue metabolism, has a high sensitivity and specificity for tumour detection in patients with CCA $(118,121)$. However, its clinical application has been limited so far $(122,123)$. Multislice threedimensional spiral computed tomography cholangiography without a biliary contrast agent but with minimum-intensity projection may become an alternative technique (124). Diagnosis can be performed by direct cholangiography. However, typical cholangiographic features of PSC make it difficult to accurately detect new, malignant strictures. An asymmetric appearance or irregular stricture margins on ERC may be particularly suggestive of malignancy (125). Cytological acquisition during ERC or percutaneous cholangiogram is an advantage over noninvasive imaging. Brush cytology studies have shown a specificity close to $100 \%$ for malignancy, but a sensitivity of only $17 \%$ to $73 \%(107,126-129)$. New diagnostic methods, such as digital image analysis and fluorescence in situ hybridization, have been developed to increase the diagnostic yield of cytology in bile duct strictures $(126,130)$.

Despite the increased risk of CCA in PSC compared with the general population, there are currently no data to support serial cholangiographic or radiological imaging alone for CCA surveillance in patients with PSC. Serum tumour markers such as carbohydrate antigen 19-9 and carcinoembryonic antigen 
lack sensitivity and specificity for the diagnosis of early stage CCA (131). Tumours often present at an advanced stage and have a poor prognosis $(132,133)$. In contrast, early-stage CCA in the setting of PSC can be amenable to successful liver transplantation in highly selected individuals, especially at centres employing neoadjuvant protocols such as radiotherapy, chemosensitizing 5-fluorouracil and subsequent capecitabine at the Mayo Clinic, and brachytherapy and continuous 5-fluoracil infusion in Nebraska (134-137). Curative resection among individuals with early-stage CCA may also be of benefit in PSC, although transplantation with neoadjuvant chemoradiation with localized, node-negative hilar CCA may achieve better survival than conventional resection, with less recurrence.

\section{Other malignancies}

Patients with PSC are at increased risk for cancers of the pancreas, gallbladder and liver $(112,138,139)$. Colon cancer risk is increased particularly if the patient has IBD $(112,140,141)$. UDCA may reduce the risk of colon dysplasia and/or cancer with long-term use $(142,143)$; however, not all studies have shown similar benefit (144).

\section{REFERENCES}

1. Wiesner RH, LaRusso NF. Clinicopathologic features of the syndrome of primary sclerosing cholangitis. Gastroenterology 1980;79:200-6.

2. Talwalkar JA, Lindor KD. Primary sclerosing cholangitis. Inflamm Bowel Dis 2005;11:62-72.

3. Bjornsson E, Angulo P. Cholangiocarcinoma in young individuals with and without primary sclerosing cholangitis. Am J Gastroenterol 2007;102:1677-82.

4. Brandsaeter B, Friman S, Broome U, et al. Outcome following liver transplantation for primary sclerosing cholangitis in the Nordic countries. Scand J Gastroenterol 2003;38:1176-83.

5. Chapman RW, Arborgh BA, Rhodes JM, et al. Primary sclerosing cholangitis: A review of its clinical features, cholangiography, and hepatic histology. Gut 1980;21:870-7.

6. Schrumpf E, Boberg KM. Epidemiology of primary sclerosing cholangitis. Best Pract Res Clin Gastroenterol 2001;15:553-62.

7. Bambha K, Kim WR, Talwalkar J, et al. Incidence, clinical spectrum, and outcomes of primary sclerosing cholangitis in a United States community. Gastroenterology 2003; 125:1364-9.

8. Olsson R, Danielsson A, Jarnerot G, et al. Prevalence of primary sclerosing cholangitis in patients with ulcerative colitis. Gastroenterology 1991;100:1319-23.

9. Boberg KM, Aadland E, Jahnsen J, Raknerud N, Stiris M, Bell H. Incidence and prevalence of primary biliary cirrhosis, primary sclerosing cholangitis, and autoimmune hepatitis in a Norwegian population. Scand J Gastroenterol 1998;33:99-103.

10. Kingham JG, Kochar N, Gravenor MB. Incidence, clinical patterns, and outcomes of primary sclerosing cholangitis in South Wales, United Kingdom. Gastroenterology 2004;126:1929-30.

11. Kaplan GG, Laupland KB, Butzner D, Urbanski SJ, Lee SS. The burden of large and small duct primary sclerosing cholangitis in adults and children: A population-based analysis. Am J Gastroenterol 2007;102:1042-9.

12. Wiesner RH, Grambsch PM, Dickson ER, et al. Primary sclerosing cholangitis: Natural history, prognostic factors and survival analysis. Hepatology 1989;10:430-6.

13. Broome U, Olsson R, Loof L, et al. Natural history and prognostic factors in 305 Swedish patients with primary sclerosing cholangitis. Gut 1996;38:610-5.

14. Okolicsanyi L, Fabris L, Viaggi S, Carulli N, Podda M, Ricci G. Primary sclerosing cholangitis: Clinical presentation, natural history and prognostic variables: An Italian multicentre study. The Italian PSC Study Group. Eur J Gastroenterol Hepatol 1996;8:685-91.

15. Olsson R, Broome U, Danielsson A, et al. Spontaneous course of symptoms in primary sclerosing cholangitis: Relationships with

\section{CONCLUSION}

PSC is a chronic cholestatic liver disease that is generally progressive, and usually leads to the development of primary biliary cirrhosis along with its complications. Other disease-specific complications of PSC include pruritus, fatigue, vitamin deficiencies, metabolic bone disease, peristomal varices, bacterial cholangitis, dominant biliary strictures, gallbladder stones and polyps, and malignancy, particularly CCA. There is no proven medical treatment available for PSC. Despite the presumed autoimmune etiology of PSC, a clear benefit from immunosuppressive agents has not been demonstrated to date and their use can be limited by side effects. Patients with PSC should be considered for therapeutic trials. Liver transplantation is currently the only life-extending therapy for patients with end-stage disease, but disease recurrence can be a source of morbidity and mortality as transplanted patients survive longer. Further studies are needed to develop an optimal therapeutic strategy for patients with PSC to decrease the incidence of complications of the disease and the need for transplantation, and to extend the life expectancy of patients with PSC.

biochemical and histological features. Hepatogastroenterology 1999;46:136-41.

16. Balasubramaniam K, Wiesner RH, LaRusso NF. Primary sclerosing cholangitis with normal serum alkaline phosphatase activity. Gastroenterology 1988;95:1395-8.

17. Bjornsson E, Lindqvist-Ottosson J, Asztely M, Olsson R. Dominant strictures in patients with primary sclerosing cholangitis. Am J Gastroenterol 2004;99:502-8.

18. Wiesner RH. Current concepts in primary sclerosing cholangitis. Mayo Clin Proc 1994;69:969-82.

19. Chapman RW, Cottone M, Selby WS, Shepherd HA, Sherlock S, Jewell DP. Serum autoantibodies, ulcerative colitis and primary sclerosing cholangitis. Gut 1986;27:86-91.

20. Mulder AH, Horst G, Haagsma EB, Limburg PC, Kleibeuker JH, Kallenberg CG. Prevalence and characterization of neutrophil cytoplasmic antibodies in autoimmune liver diseases. Hepatology 1993;17:411-7.

21. Bansi D, Chapman R, Fleming K. Antineutrophil cytoplasmic antibodies in chronic liver diseases: Prevalence, titre, specificity and IgG subclass. J Hepatol 1996;24:581-6.

22. Chapman RW. The enigma of anti-neutrophil antibodies in ulcerative colitis primary sclerosing cholangitis: Important genetic marker or epiphenomenon? Hepatology 1995;21:1473-4.

23. MacCarty RL, LaRusso NF, Wiesner RH, Ludwig J. Primary sclerosing cholangitis: Findings on cholangiography and pancreatography. Radiology 1983;149:39-44.

24. Bilbao MK, Dotter CT, Lee TG, Katon RM. Complications of endoscopic retrograde cholangiopancreatography (ERCP). A study of 10,000 cases. Gastroenterology 1976;70:314-20.

25. Freeman ML, Nelson DB, Sherman S, et al. Complications of endoscopic biliary sphincterotomy. N Engl J Med 1996;335:909-18

26. Talwalkar JA, Angulo P, Johnson CD, Petersen BT, Lindor KD. Cost-minimization analysis of MRC versus ERCP for the diagnosis of primary sclerosing cholangitis. Hepatology 2004;40:39-45.

27. Etzel JP, Eng SC, Ko CW, et al. Complications after ERCP in patients with primary sclerosing cholangitis. Gastrointest Endosc 2008;67:643-8.

28. Mehta SN, Reinhold C, Barkun AN. Magnetic resonance cholangiopancreatography. Gastrointest Endosc Clin N Am $1997 ; 7: 247-70$

29. Charatcharoenwitthaya P, Lindor KD. Primary sclerosing cholangitis: Diagnosis and management. Curr Gastroenterol Rep 2006;8:75-82.

30. Ludwig J. Surgical pathology of the syndrome of primary sclerosing cholangitis. Am J Surg Pathol 1989;13(Suppl 1):43-9.

31. Scheuer PJ. Ludwig Symposium on biliary disorders - part II. Pathologic features and evolution of primary biliary cirrhosis and primary sclerosing cholangitis. Mayo Clin Proc 1998;73:179-83. 
32. Burak KW, Angulo P, Lindor KD. Is there a role for liver biopsy in primary sclerosing cholangitis? Am J Gastroenterol 2003;98:1155-8.

33. Ludwig J, Dickson ER, McDonald GS. Staging of chronic nonsuppurative destructive cholangitis (syndrome of primary biliary cirrhosis). Virchows Arch A Pathol Anat Histol 1978;379:103-12.

34. Kim WR, Therneau TM, Wiesner RH, et al. A revised natural history model for primary sclerosing cholangitis. Mayo Clin Proc 2000;75:688-94.

35. Angulo P, Batts KP, Jorgensen RA, LaRusso NA, Lindor KD. Oral budesonide in the treatment of primary sclerosing cholangitis. Am J Gastroenterol 2000;95:2333-7.

36. Olsson R, Broome U, Danielsson A, et al. Colchicine treatment of primary sclerosing cholangitis. Gastroenterology 1995;108:1199-203.

37. Duchini A, Younossi ZM, Saven A, Bordin GM, Knowles HJ, Pockros PJ. An open-label pilot trial of cladibrine (2-cholordeoxyadenosine) in patients with primary sclerosing cholangitis. J Clin Gastroenterol 2000;31:292-6.

38. Sandborn WJ, Wiesner RH, Tremaine WJ, Larusso NF. Ulcerative colitis disease activity following treatment of associated primary sclerosing cholangitis with cyclosporin. Gut 1993;34:242-6.

39. Epstein MP, Kaplan MM. A pilot study of etanercept in the treatment of primary sclerosing cholangitis. Dig Dis Sci 2004;49:1-4

40. Hommes DW, Erkelens W, Ponsioen C, et al. A double-blind placebo-controlled, randomized study of infliximab in primary sclerosing cholangitis. J Clin Gastroenterol 2008;42:522-6.

41. Knox TA, Kaplan MM. A double-blind controlled trial of oral-pulse methotrexate therapy in the treatment of primary sclerosing cholangitis. Gastroenterology 1994;106:494-9.

42. Talwalkar JA, Angulo P, Keach JC, Petz JL, Jorgensen RA, Lindor KD. Mycophenolate mofetil for the treatment of primary sclerosing cholangitis. Am J Gastroenterol 2005;100:308-12.

43. Sterling RK, Salvatori JJ, Luketic VA, et al. A prospective, randomized-controlled pilot study of ursodeoxycholic acid combined with mycophenolate mofetil in the treatment of primary sclerosing cholangitis. Aliment Pharmacol Ther 2004;20:943-9.

44. Angulo P, Bharucha AE, Jorgensen RA, et al. Oral nicotine in treatment of primary sclerosing cholangitis: A pilot study. Dig Dis Sci 1999;44:602-7.

45. Vleggaar FP, van Buuren HR, van Berge Henegouwen GP, Hop WC, van Erpecum KJ. No beneficial effects of transdermal nicotine in patients with primary sclerosing cholangitis: Results of a randomized double-blind placebo-controlled cross-over study. Eur J Gastroenterol Hepatol 2001;13:171-5.

46. LaRusso NF, Wiesner RH, Ludwig J, MacCarty RL, Beaver SJ, Zinsmeister AR. Prospective trial of penicillamine in primary sclerosing cholangitis. Gastroenterology 1988;95:1036-42.

47. Bharucha AE, Jorgensen R, Lichtman SN, LaRusso NF, Lindor KD. A pilot study of pentoxifylline for the treatment of primary sclerosing cholangitis. Am J Gastroenterol 2000;95:2338-42.

48. Angulo P, MacCarty RL, Sylvestre PB, et al. Pirfenidone in the treatment of primary sclerosing cholangitis. Dig Dis Sci 2002;47:157-61.

49. Angulo P, Jorgensen RA, Kowdley KV, Lindor KD. Silymarin in the treatment of patients with primary sclerosing cholangitis: An openlabel pilot study. Dig Dis Sci 2007 Oct 17 (Epub ahead of print).

50. Van Thiel DH, Carroll P, Abu-Elmagd K, et al. Tacrolimus (FK 506), a treatment for primary sclerosing cholangitis: Results of an open-label preliminary trial. Am J Gastroenterol 1995;90:455-9.

51. Talwalkar JA, Gossard AA, Keach JC, Jorgensen RA, Petz JL, Lindor RN. Tacrolimus for the treatment of primary sclerosing cholangitis. Liver Int 2007;27:451-3.

52. Lindor KD, Wiesner RH, Colwell LJ, Steiner B, Beaver S, LaRusso NF The combination of prednisone and colchicine in patients with primary sclerosing cholangitis. Am J Gastroenterol 1991;86:57-61.

53. Lindor KD, Jorgensen RA, Anderson ML, Gores GJ, Hofmann AF, LaRusso NF. Ursodeoxycholic acid and methotrexate for primary sclerosing cholangitis: A pilot study. Am J Gastroenterol 1996;91:511-5.

54. van Hoogstraten HJ, Vleggaar FP, Boland GJ, et al. Budesonide or prednisone in combination with ursodeoxycholic acid in primary sclerosing cholangitis: A randomized double-blind pilot study. Belgian-Dutch PSC Study Group. Am J Gastroenterol 2000;95:2015-22.
55. Schramm C, Schirmacher P, Helmreich-Becker I, Gerken G, zum Buschenfelde KH, Lohse AW. Combined therapy with azathioprine, prednisolone, and ursodiol in patients with primary sclerosing cholangitis. A case series. Ann Intern Med 1999;131:943-6.

56. Farkkila M, Karvonen AL, Nurmi H, et al. Metronidazole and ursodeoxycholic acid for primary sclerosing cholangitis: A randomized placebo-controlled trial. Hepatology 2004;40:1379-86

57. Silveira MG, Lindor KD. High dose ursodeoxycholic acid for the treatment of primary sclerosing cholangitis. J Hepatol 2008;48:692-4.

58. Lindor KD. Ursodiol for primary sclerosing cholangitis. Mayo Primary Sclerosing Cholangitis-Ursodeoxycholic Acid Study Group. N Engl J Med 1997;336:691-5.

59. Mitchell SA, Bansi DS, Hunt N, Von Bergmann K, Fleming KA Chapman RW. A preliminary trial of high-dose ursodeoxycholic acid in primary sclerosing cholangitis. Gastroenterology 2001;121:900-7.

60. Olsson R, Boberg KM, de Muckadell OS, et al. High-dose ursodeoxycholic acid in primary sclerosing cholangitis: A 5-year multicenter, randomized, controlled study. Gastroenterology 2005; 129:1464-72.

61. Harnois DM, Angulo P, Jorgensen RA, Larusso NF, Lindor KD. High-dose ursodeoxycholic acid as a therapy for patients with primary sclerosing cholangitis. Am J Gastroenterol 2001;96:1558-62

62. Cullen SN, Rust C, Fleming K, Edwards C, Beuers U, Chapman RW. High dose ursodeoxycholic acid for the treatment of primary sclerosing cholangitis is safe and effective. J Hepatol 2008;48:792-800.

63. Hoofnagle JH. Primary sclerosing cholangitis. Hepatology 2005;41:955.

64. Pall H, Zaman MM, Andersson C, Freedman SD. Decreased peroxisome proliferator activated receptor alpha is associated with bile duct injury in cystic fibrosis transmembrane conductance regulator -/- mice. J Pediatr Gastroenterol Nutr 2006;42:275-81.

65. Fickert P, Wagner M, Marschall HU, et al. 24-norursodeoxycholic acid is superior to ursodeoxycholic acid in the treatment of sclerosing cholangitis in Mdr2 (Abcb4) knockout mice. Gastroenterology 2006;130:465-81.

66. Pellicciari R, Fiorucci S, Camaioni E, et al. 6alpha-ethylchenodeoxycholic acid (6-ECDCA), a potent and selective FXR agonist endowed with anticholestatic activity. J Med Chem 2002;45:3569-72

67. Fiorucci S, Clerici C, Antonelli E, et al. Protective effects of 6-ethyl chenodeoxycholic acid, a farnesoid X receptor ligand, in estrogen-induced cholestasis. J Pharmacol Exp Ther 2005;313:604-12.

68. Fiorucci S, Antonelli E, Rizzo G, et al. The nuclear receptor SHP mediates inhibition of hepatic stellate cells by FXR and protects against liver fibrosis. Gastroenterology 2004;127:1497-512.

69. Pellicciari R, Costantino G, Fiorucci S. Farnesoid X receptor: From structure to potential clinical applications. J Med Chem 2005;48:5383-403

70. Kaya M, Petersen BT, Angulo P, et al. Balloon dilation compared to stenting of dominant strictures in primary sclerosing cholangitis. Am J Gastroenterol 2001;96:1059-66.

71. Angulo P, Lindor KD. Primary sclerosing cholangitis. Hepatology 1999;30:325-32.

72. Linder S, Soderlund C. Endoscopic therapy in primary sclerosing cholangitis: Outcome of treatment and risk of cancer. Hepatogastroenterology 2001;48:387-92.

73. Stiehl A, Rudolph G, Sauer P, et al. Efficacy of ursodeoxycholic acid treatment and endoscopic dilation of major duct stenoses in primary sclerosing cholangitis. An 8-year prospective study. J Hepatol 1997;26:560-6.

74. Baluyut AR, Sherman S, Lehman GA, Hoen H, Chalasani N Impact of endoscopic therapy on the survival of patients with primary sclerosing cholangitis. Gastrointest Endosc 2001;53:308-12.

75. Domajnko B, Ahrendt SA. Indications for non-transplant surgery in primary sclerosing cholangitis. HPB (Oxford) 2005; 7:292-7.

76. McEntee G, Wiesner RH, Rosen C, Cooper J, Wahlstrom E. A comparative study of patients undergoing liver transplantation for primary sclerosing cholangitis and primary biliary cirrhosis. Transplant Proc 1991;23:1563-4. 
77. Muiesan P, Shanmugam RP, Devlin J, et al. Orthotopic liver transplantation for primary sclerosing cholangitis. Transplant Proc 1994:26:3574-6.

78. Farges O, Malassagne B, Sebagh M, Bismuth H. Primary sclerosing cholangitis: Liver transplantation or biliary surgery. Surgery 1995;117:146-55

79. Narumi S, Roberts JP, Emond JC, Lake J, Ascher NL. Liver transplantation for sclerosing cholangitis. Hepatology 1995;22:451-7.

80. Ahrendt SA, Pitt HA, Kalloo AN, et al. Primary sclerosing cholangitis: Resect, dilate, or transplant? Ann Surg 1998:227:412-23.

81. Nashan B, Schlitt HJ, Tusch G, et al. Biliary malignancies in primary sclerosing cholangitis: Timing for liver transplantation. Hepatology 1996;23:1105-11.

82. Lee J, Belanger A, Doucette JT, Stanca C, Friedman S, Bach N. Transplantation trends in primary biliary cirrhosis. Clin Gastroenterol Hepatol 2007;5:1313-5.

83. Roberts MS, Angus DC, Bryce CL, Valenta Z, Weissfeld L. Survival after liver transplantation in the United States: A disease-specific analysis of the UNOS database. Liver Transpl 2004;10:886-97.

84. Merion RM. When is a patient too well and when is a patient too sick for a liver transplant? Liver Transpl 2004;10(10 Suppl 2):S69-73.

85. LaRusso NF, Shneider BL, Black D, et al. Primary sclerosing cholangitis: Summary of a workshop. Hepatology 2006;44:746-64.

86. Gautam M, Cheruvattath R, Balan V. Recurrence of autoimmune liver disease after liver transplantation: A systematic review. Liver Transpl 2006;12:1813-24.

87. Khettry U, Keaveny A, Goldar-Najafi A, et al. Liver transplantation for primary sclerosing cholangitis: A long-term clinicopathologic study. Hum Pathol 2003;34:1127-36.

88. Brandsaeter B, Schrumpf E, Clausen OP, Abildgaard A, Hafsahl G, Bjoro K. Recurrent sclerosing cholangitis or ischemic bile duct lesions - a diagnostic challenge? Liver Transpl 2004;10:1073-4.

89. Graziadei IW, Wiesner RH, Batts KP, et al. Recurrence of primary sclerosing cholangitis following liver transplantation. Hepatology 1999:29:1050-6.

90. Charatcharoenwitthaya P, Lindor KD. Recurrence of primary sclerosing cholangitis: What do we learn from several transplant centers? Liver Transpl 2008;14:130-2.

91. Jeyarajah DR, Netto GJ, Lee SP, et al. Recurrent primary sclerosing cholangitis after orthotopic liver transplantation: Is chronic rejection part of the disease process? Transplantation 1998;66:1300-6.

92. Vera A, Moledina S, Gunson B, et al. Risk factors for recurrence of primary sclerosing cholangitis of liver allograft. Lancet 2002;360:1943-4

93. Tamura S, Sugawara Y, Kaneko J, Matsui Y, Togashi J, Makuuchi M. Recurrence of primary sclerosing cholangitis after living donor liver transplantation. Liver Int 2007;27:86-94.

94. Alexander J, Lord JD, Yeh MM, Cuevas C, Bakthavatsalam R, Kowdley KV. Risk factors for recurrence of primary sclerosing cholangitis after liver transplantation. Liver Transpl 2008; $14: 245-51$

95. Brandsaeter B, Schrumpf E, Bentdal O, et al. Recurrent primary sclerosing cholangitis after liver transplantation: A magnetic resonance cholangiography study with analyses of predictive factors. Liver Transpl 2005;11:1361-9.

96. Kugelmas M, Spiegelman P, Osgood MJ, et al. Different immunosuppressive regimens and recurrence of primary sclerosing cholangitis after liver transplantation. Liver Transpl 2003;9:727-32.

97. Cholongitas E, Shusang V, Papatheodoridis GV, et al. Risk factors for recurrence of primary sclerosing cholangitis after liver transplantation. Liver Transpl 2008;14:138-43.

98. Farrant JM, Hayllar KM, Wilkinson ML, et al. Natural history and prognostic variables in primary sclerosing cholangitis. Gastroenterology 1991;100:1710-7.

99. Ponsioen CY, Vrouenraets SM, Prawirodirdjo W, et al. Natural history of primary sclerosing cholangitis and prognostic value of cholangiography in a Dutch population. Gut 2002;51:562-6.

100. Mendes FD, Kim WR, Pedersen R, Therneau T, Lindor KD. Mortality attributable to cholestatic liver disease in the United States. Hepatology 2008;47:1241-7.

101. Dickson ER, Murtaugh PA, Wiesner RH, et al. Primary sclerosing cholangitis: Refinement and validation of survival models. Gastroenterology 1992;103:1893-901.
102. Shetty K, Rybicki L, Carey WD. The Child-Pugh classification as a prognostic indicator for survival in primary sclerosing cholangitis. Hepatology 1997;25:1049-53.

103. Kim WR, Poterucha JJ, Wiesner RH, et al. The relative role of the Child-Pugh classification and the Mayo natural history model in the assessment of survival in patients with primary sclerosing cholangitis. Hepatology 1999;29:1643-8.

104. Talwalkar JA, Lindor KD. Natural history and prognostic models in primary sclerosing cholangitis. Best Pract Res Clin Gastroenterol 2001;15:563-75.

105. Boberg KM, Rocca G, Egeland T, et al. Time-dependent Cox regression model is superior in prediction of prognosis in primary sclerosing cholangitis. Hepatology 2002;35:652-7.

106. Helzberg JH, Petersen JM, Boyer JL. Improved survival with primary sclerosing cholangitis. A review of clinicopathologic features and comparison of symptomatic and asymptomatic patients. Gastroenterology 1987;92:1869-75.

107. Lindberg B, Arnelo U, Bergquist A, et al. Diagnosis of biliary strictures in conjunction with endoscopic retrograde cholangiopancreaticography, with special reference to patients with primary sclerosing cholangitis. Endoscopy 2002;34:909-16

108. Craig DA, MacCarty RL, Wiesner RH, Grambsch PM, LaRusso NF. Primary sclerosing cholangitis: Value of cholangiography in determining the prognosis. AJR Am J Roentgenol 1991;157:959-64.

109. Olsson RG, Asztely MS. Prognostic value of cholangiography in primary sclerosing cholangitis. Eur J Gastroenterol Hepatol 1995;7:251-4.

110. Burak K, Angulo P, Pasha TM, Egan K, Petz J, Lindor KD. Incidence and risk factors for cholangiocarcinoma in primary sclerosing cholangitis. Am J Gastroenterol 2004;99:5236.

111. Kornfeld D, Ekbom A, Ihre T. Survival and risk of cholangiocarcinoma in patients with primary sclerosing cholangitis A population-based study. Scand J Gastroenterol 1997;32:1042-5.

112. Bergquist A, Ekbom A, Olsson R, et al. Hepatic and extrahepatic malignancies in primary sclerosing cholangitis. J Hepatol 2002;36:321-7

113. Brandsaeter B, Isoniemi $\mathrm{H}$, Broome $\mathrm{U}$, et al. Liver transplantation for primary sclerosing cholangitis; predictors and consequences of hepatobiliary malignancy. J Hepatol 2004:40:815-22.

114. Rudolph G, Kloeters-Plachky P, Rost D, Stiehl A. The incidence of cholangiocarcinoma in primary sclerosing cholangitis after long-time treatment with ursodeoxycholic acid. Eur J Gastroentero Hepatol 2007;19:487-91.

115. Lazaridis KN. Dissecting the genetic susceptibility for cholangiocarcinoma in primary sclerosing cholangitis. Hepatology 2008;47:8-10.

116. Kaya M, de Groen PC, Angulo P, et al. Treatment of cholangiocarcinoma complicating primary sclerosing cholangitis: The Mayo Clinic experience. Am J Gastroenterol 2001;96:1164-9.

117. Yachimski P, Pratt DS. Cholangiocarcinoma: Natural history, treatment, and strategies for surveillance in high-risk patients. J Clin Gastroenterol 2008;42:178-90.

118. Prytz H, Keiding S, Bjornsson E, et al; Swedish Internal Medicine Liver Club. Dynamic FDG-PET is useful for detection of cholangiocarcinoma in patients with PSC listed for liver transplantation. Hepatology 2006;44:1572-80.

119. Angulo P, Pearce DH, Johnson CD, et al. Magnetic resonance cholangiography in patients with biliary disease: Its role in primary sclerosing cholangitis. J Hepatol 2000;33:520-7.

120. Moreno Luna LE, Gores GJ. Advances in the diagnosis of cholangiocarcinoma in patients with primary sclerosing cholangitis Liver Transpl 2006;12(11 Suppl 2):S15-9.

121. Kluge R, Schmidt F, Caca K, et al. Positron emission tomography with [(18)Flfluoro-2-deoxy-D-glucose for diagnosis and staging of bile duct cancer. Hepatology 2001;33:1029-35.

122. Fevery J, Buchel O, Nevens F, Verslype C, Stroobants S, Van Steenbergen W. Positron emission tomography is not a reliable method for the early diagnosis of cholangiocarcinoma in patients with primary sclerosing cholangitis. J Hepatol 2005;43:358-60.

123. Anderson CD, Rice MH, Pinson CW, Chapman WC, Chari RS, Delbeke D. Fluorodeoxyglucose PET imaging in the evaluation of gallbladder carcinoma and cholangiocarcinoma. J Gastrointest Surg 2004:8:90-7.

124. Zandrino F, Curone P, Benzi L, Ferretti ML, Musante F. MR versus multislice CT cholangiography in evaluating patients with obstruction of the biliary tract. Abdom Imaging 2005;30:77-85. 
125. Park MS, Kim TK, Kim KW, et al. Differentiation of extrahepatic bile duct cholangiocarcinoma from benign stricture: Findings at MRCP versus ERCP. Radiology 2004;233:234-40.

126. Moreno Luna LE, Kipp B, Halling KC, et al. Advanced cytologic techniques for the detection of malignant pancreatobiliary strictures. Gastroenterology 2006;131:1064-72.

127. Rabinovitz M, Zajko AB, Hassanein T, et al. Diagnostic value of brush cytology in the diagnosis of bile duct carcinoma: A study in 65 patients with bile duct strictures. Hepatology 1990;12:747-52.

128. Boberg KM, Jebsen P, Clausen OP, Foss A, Aabakken L, Schrumpf E. Diagnostic benefit of biliary brush cytology in cholangiocarcinoma in primary sclerosing cholangitis. J Hepatol 2006;45:568-74.

129. Furmanczyk PS, Grieco VS, Agoff SN. Biliary brush cytology and the detection of cholangiocarcinoma in primary sclerosing cholangitis: Evaluation of specific cytomorphologic features and CA19-9 levels. Am J Clin Pathol 2005;124:355-60.

130. Kipp BR, Stadheim LM, Halling SA, et al. A comparison of routine cytology and fluorescence in situ hybridization for the detection of malignant bile duct strictures. Am J Gastroenterol 2004;99:1675-81

131. Levy C, Lymp J, Angulo P, Gores GJ, Larusso N, Lindor KD. The value of serum CA 19-9 in predicting cholangiocarcinomas in patients with primary sclerosing cholangitis. Dig Dis Sci 2005;50:1734-40

132. Rosen CB, Nagorney DM, Wiesner RH, Coffey RJ Jr, LaRusso NF Cholangiocarcinoma complicating primary sclerosing cholangitis. Ann Surg 1991;213:21-5.

133. Wiesner RH, Porayko MK, Dickson ER, et al. Selection and timing of liver transplantation in primary biliary cirrhosis and primary sclerosing cholangitis. Hepatology 1992;16:1290-9.

134. Graziadei IW, Wiesner RH, Marotta PJ, et al. Long-term results of patients undergoing liver transplantation for primary sclerosing cholangitis. Hepatology 1999;30:1121-7.

135. Heimbach JK, Gores GJ, Nagorney DM, Rosen CB. Liver transplantation for perihilar cholangiocarcinoma after aggressive neoadjuvant therapy: A new paradigm for liver and biliary malignancies? Surgery 2006;140:331-4.

136. Rea DJ, Heimbach JK, Rosen CB, et al. Liver transplantation with neoadjuvant chemoradiation is more effective than resection for hilar cholangiocarcinoma. Ann Surg 2005;242:451-8; discussion 458-61.

137. Sudan D, DeRoover A, Chinnakotla S, et al. Radiochemotherapy and transplantation allow long-term survival for nonresectable hilar cholangiocarcinoma. Am J Transplant 2002;2:774-9.

138. Harnois DM, Gores GJ, Ludwig J, Steers JL, LaRusso NF, Wiesner RH. Are patients with cirrhotic stage primary sclerosing cholangitis at risk for the development of hepatocellular cancer? J Hepatol 1997;27:512-6.

139. Lewis JT, Talwalkar JA, Rosen CB, Smyrk TC, Abraham SC. Prevalence and risk factors for gallbladder neoplasia in patients with primary sclerosing cholangitis: Evidence for a metaplasiadysplasia-carcinoma sequence. Am J Surg Pathol 2007;31:907-13.

140. Broome U, Lofberg R, Veress B, Eriksson LS. Primary sclerosing cholangitis and ulcerative colitis: Evidence for increased neoplastic potential. Hepatology 1995;22:1404-8.
141. Kornfeld D, Ekbom A, Ihre T. Is there an excess risk for colorectal cancer in patients with ulcerative colitis and concomitant primary sclerosing cholangitis? A population based study. Gut 1997;41:522-5.

142. Tung BY, Emond MJ, Haggitt RC, et al. Ursodiol use is associated with lower prevalence of colonic neoplasia in patients with ulcerative colitis and primary sclerosing cholangitis. Ann Intern Med 2001;134:89-95.

143. Pardi DS, Loftus EV Jr, Kremers WK, Keach J, Lindor KD. Ursodeoxycholic acid as a chemopreventive agent in patients with ulcerative colitis and primary sclerosing cholangitis. Gastroenterology 2003;124:889-93.

144. Wolf JM, Rybicki LA, Lashner BA. The impact of ursodeoxycholic acid on cancer, dysplasia and mortality in ulcerative colitis patients with primary sclerosing cholangitis. Aliment Pharmacol Ther 2005;22:783-8

145. Porayko MK, Wiesner RH, LaRusso NF, et al. Patients with asymptomatic primary sclerosing cholangitis frequently have progressive disease. Gastroenterology 1990;93:1594-602.

146. Gossard AA, Angulo P, Lindor KD. Secondary sclerosing cholangitis: A comparison to primary sclerosing cholangitis. Am J Gastroenterol 2005;100:1330-3.

147. Dhiman RK, Behera A, Chawla YK, Dilawari JB, Suri S. Portal hypertensive biliopathy. Gut 2007;56:1001-8.

148. Gelbmann CM, Rummele P, Wimmer M, et al. Ischemic-like cholangiopathy with secondary sclerosing cholangitis in critically ill patients. Am J Gastroenterol 2007;102:1221-9.

149. Kaya M, Angulo P, Lindor KD. Overlap of autoimmune hepatitis and primary sclerosing cholangitis: An evaluation of a modified scoring system. J Hepatol 2000;33:537-42.

150. Bjornsson E, Chari ST, Smyrk TC, Lindor K. Immunoglobulin G4 associated cholangitis: Description of an emerging clinical entity based on review of the literature. Hepatology 2007;45:1547-54.

151. Polter DE, Gruhl V, Eigenbrodt EH, Combes B. Beneficial effect of cholestyramine in sclerosing cholangitis. Gastroenterology 1980;79:326-33.

152. Tahibian N. Rifampin as antipruritic agent in primary sclerosing cholangitis. Am J Gastroenterol 1989;84:340.

153. Wolfhagen FH, Sternieri E, Hop WC, Vitale G, Bertolotti M, Van Buuren HR. Oral naltrexone treatment for cholestatic pruritis: A double-blind, placebo-controlled study. Gastroenterology 1997;113:1264-9.

154. Bergassa NV, Aling DW, Talbot TL, et al. Effects of naloxone infusions in patients with the pruritis of cholestasis. A double blind, placebo-controlled study. Gastroenterology 1997;113:1264-9.

155. Mayo MJ, Handern I, Saldana S, Jacobe H, Getachew Y, Rush AJ. Sertraline as a first-line treatment for cholestatic pruritis. Hepatology 2007;45:666-74.

156. Jones EA, Molenaar HA, Oosting J. Ondansetron and pruritis in chronic liver disease: A controlled study. Hepatogastroenterology 2007;54:1196-9.

157. Leung UC, Wong PY, Roberts RH, Koea JB. Gall bladder polyps in sclerosing cholangitis: Does the $1-\mathrm{cm}$ rule apply? ANZ J Surg 2007;77:355-7.

158. Baron TH. Photodynamic therapy: Standard of care for palliation of cholangiocarcinoma? Clin Gastroenterol Hepatol 2008;6:266-7. 


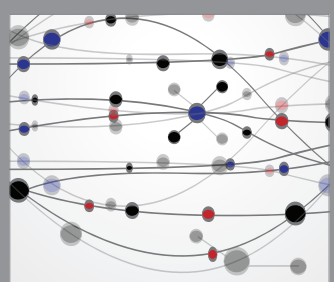

The Scientific World Journal
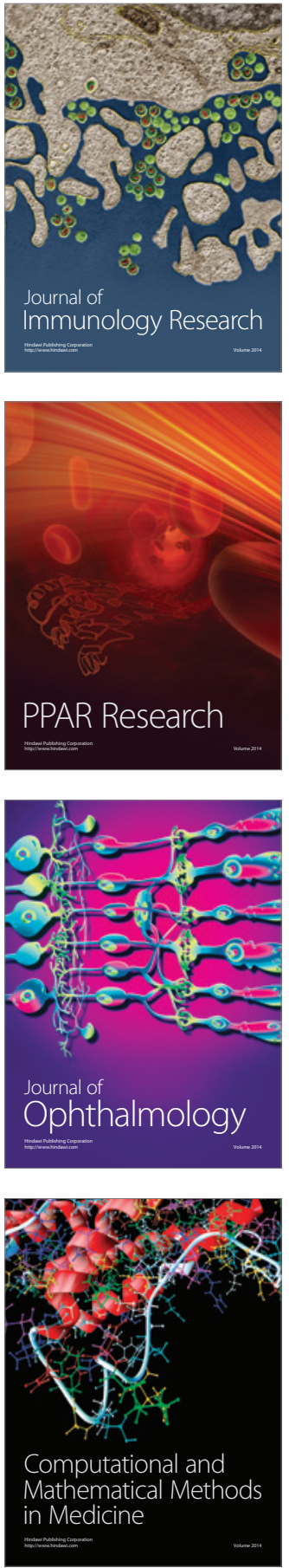

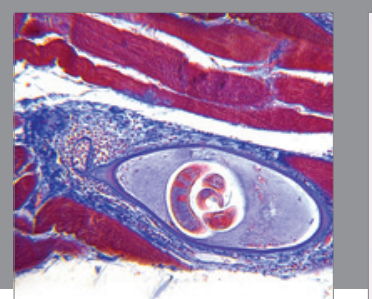

Gastroenterology Research and Practice

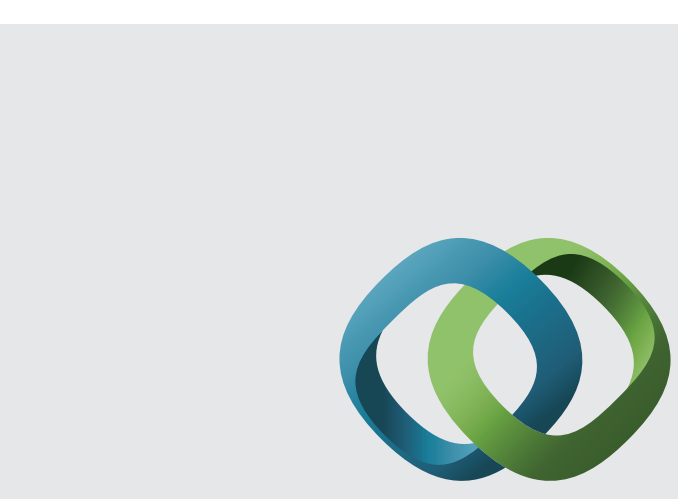

\section{Hindawi}

Submit your manuscripts at

http://www.hindawi.com
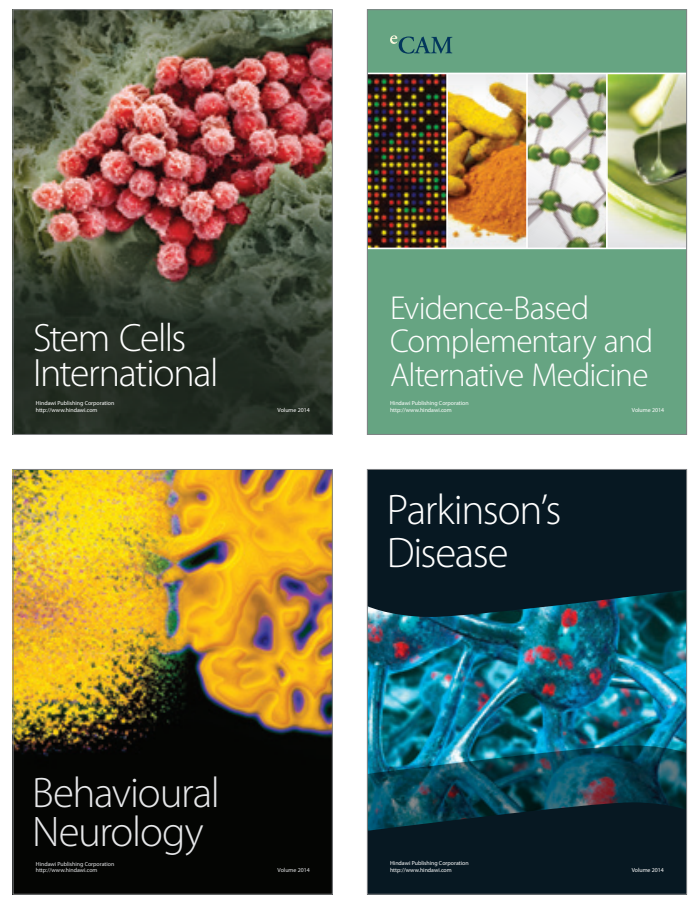
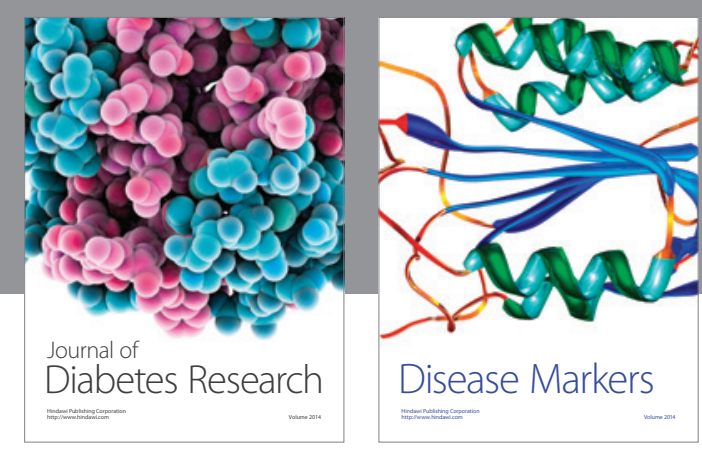

Disease Markers
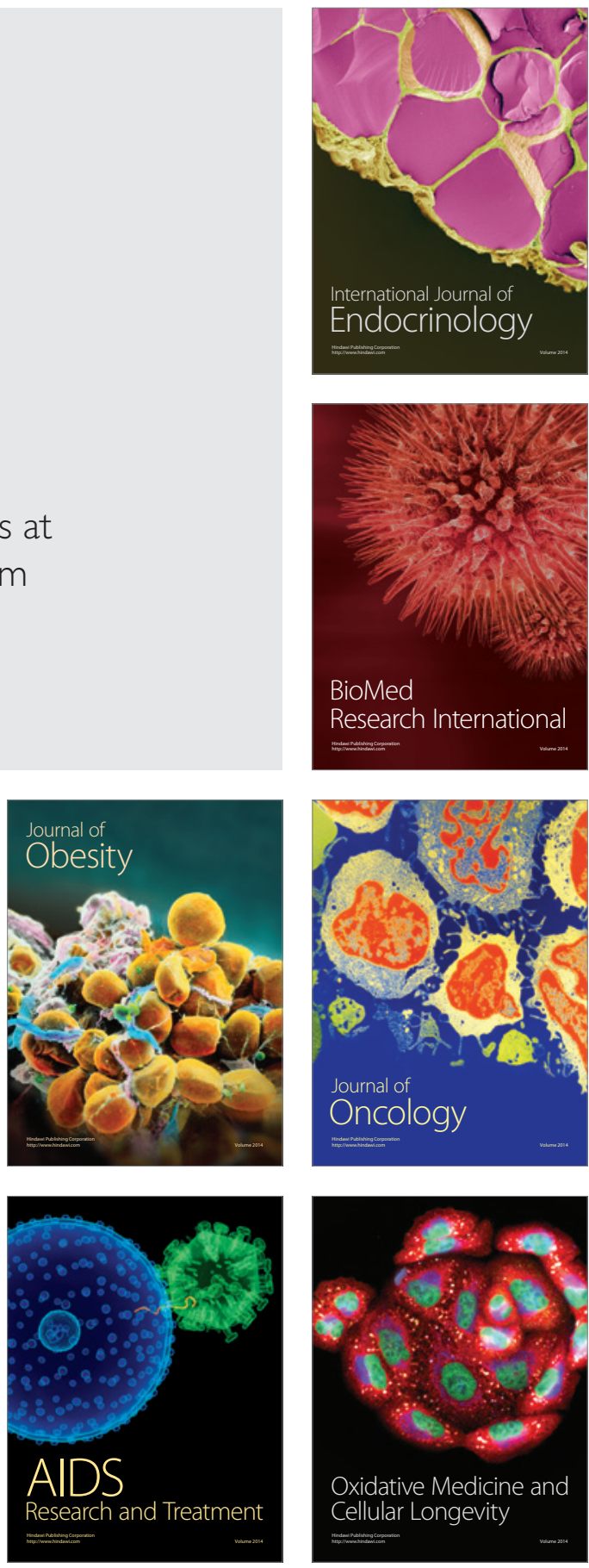